\title{
The Physical and Chemical Characteristics of Potato Doughnuts Using Semi-Liquid Local Yeast Derived from Myrrh of Red Fermented Palm Sap
}

\author{
Regina Ilse Marcelina BanoEt ${ }^{1}$, \\ ${ }^{1}$ Faculty of Agriculture Technology, Artha Wacana Christian University Kupang, 147 \\ Adisucipto St, Oesapa- Kupang, Indonesia
}

\begin{abstract}
Natural or local yeasts are microorganisms from natural ingredients obtained from fermentation without the need for artificial additives. The objectives of the present study were 1.) to evaluate the physical quality of potato doughnuts produced from the local yeast derived from residue of red fermented palm sap, 2) to obtain the best treatment from the use of local yeast in making doughnuts. In the fermentation process, yeast converts sugar and carbohydrates in the dough into carbon dioxide gas $\left(\mathrm{CO}_{2}\right)$ and alcohol. Doughnuts are made from wheat flour, but the addition of potato paste can improve the texture so that it is softer and tender due to the interaction between gelatinized starch and gluten but can reduce its swelling power. The experiment was designed using a completely randomized design (CRD) with three treatments and five replications to produce 15 experimental units. The treatments were a) Control (commercial yeast); b) Wheat flour: potato paste: local yeast; $2: 1: 1$; c) Wheat flour: potato paste: local yeast; 2:1:2 and d) Wheat flour: potato paste: local yeast; 2:1:3. The results showed that the best treatment formula was obtained in the treatment B (wheat flour: potato paste: local yeast; 2:1:1) with $20,6 \%$ moisture content, $2,09 \%$ protein content and 3,644 color value (very like), 3,800 taste value (very like) and texture/tenderness with a value of 1032,500.
\end{abstract}

Keywords : Potato Donut, Moisture Content, Organoleptic, Local Yeast

*Corresponding Author:

E-mail: reginailse74@yahoo.com (Regina Ilse Marcelina BanoEt)

Faculty of Agriculture Technology, Artha Wacana Christian University Kupang, 147 Adisucipto St, Oesapa- Kupang, Indonesia

\section{INTRODUCTION}

\subsection{Research Background}

Yeast is a living microorganism from the fungus family, the species of Saccharomyces cerevisiae. The function of yeast is to ferment the dough so that the dough can expand and form fibers or bread pores. During the fermentation process, yeast converts sugars and carbohydrates in the dough into carbon dioxide gas $(\mathrm{CO} 2)$ and alcohol. The formation of this $\mathrm{CO} 2$ makes the dough expand and smells typical of bread when baked (Apriyantono, 2009).

Study conducted by (BanoEt, 2017) proved that the palm (Lontar) sap which has been processed into alcoholic beverages, especially red laru, can be extracted the myrrh and made a culture collection or can also be directly applied in making bread and various kinds of diversification, such as doughnuts.

Natural or local yeast are microorganisms obtained from natural ingredients through fermentation without the addition of artificial additives. Microorganisms in natural ingredients use glucose and produce carbon dioxide, alcohol aroma, and organic acids using beneficial microorganisms derived from natural ingredients (Ko Sangjin, 2012).

The myrrh local yeast of palm sap is obtained from tapping (sap) of stalks of lontar (palm flower; Borassus flabellifer L.) which is then stored in a container such as a
Journal Homepage:

http://ejournal.undwi.ac.id/index.php/jsds
Copyright (C) 2021 Dwijendra University. All right reserved. 
bucket, and left to allow a natural fermentation and precipitation processes to occur in the container. The natural fermentation of sap will convert sugar (glucose) to alcohol (Budiyanto, 2004). Originally, palm sap contains Saccharomycestuac yeast cells, thus lontar (palm) sap contains a substance for bread dough development. The fermented myrrh or the sediment of laru beverages is used as a starter in making doughnuts.

Makandolu in (BanoEt et al., 2018) reported that the optimum ratio between local yeast (obtained from red fermented palm sap) and wheat flour in making bread was 1: 2, with the best product had $25.6 \%$ moisture content, $14.927 \%$ expansion volume, color score of 3.711 (very like hedonic scale), aroma score 3.822 (really like hedonic scale), taste value 3.756 (very like hedonic scale) and texture 3.844 (really like hedonic scale).

Currently, various types of processed food diversification can be found in the market, one of which is doughnuts. Doughnuts are small cakes that have a very distinctive shape with a hole in the middle like a ring. There are different varieties of doughnuts flavors resulting from different topping, such as powdered sugar, melted chocolate, chocolate grains. This things make doughnuts are not only liked by adults but also children. Wheat-based doughnuts can also be added with potato paste or potato flour.

The addition of potato paste in the formula can improve the texture so that it is softer and softer due to the interaction between gelatinized starch and gluten but can reduce its swelling power. So far, there has been no research on the characteristics of potato doughnuts added with local yeast myrrh, so it is necessary to conduct a research with the topic "The physical quality of potato doughnuts using semi liquid local yeast derived from myrrh of red fermented palm sap."

\subsection{Research Problem Formulation}

Based on the background explanation, thus it is formulated the research problem as follows

1. What are the characteristics of potato doughnuts produced by using the local yeast obtained from the myrrh of red fermented sap?

2. Are there any effects of using myrrh of red fermented sap in making potato doughnuts?

\subsection{Research Objective and Benefits}

1. To obtain scientific data related to the moisture content and level of tenderness, acceptance of the taste, color, and aroma of potato doughnuts made from local yeast of myrrh of red fermented sap.

2. To obtain data related to the effect of the use of local yeast originating from myrrh of red fermented palm sap on potato doughnuts produced.

3. To obtain the best treatment that can be recommended for users, both students, and home industries.

\section{METHODS}

\section{Location and Time of Research}

The present study was conducted in three stages: 1) the production of local yeast, 2) potato paste production at the FTP Engineering Lab, and 3) the moisture content determination of potato paste at the EKSAKTA Laboratory Artha Wacana Christian University (AWCU).

\section{Ingredients and Equipment}

The ingredients used in the present study were potato paste, high protein flour (Cakra Twins), and local yeast obtained from red fermented palm sap. 


\section{Food additives}

Food additives used in the present study were instant yeast (fermipan) for control treatment, sugar (local), eggs, margarine (blueband), milk powder (dancow fullcream), salt, cooking oil (golden key), and water.

The equipment used in the present study includes a desiccator, oven, porcelain dish, mixer, plastic spoon, coconut milk sieve, glass jar, kitchen scale, OHAUS analytical scale, knife, basin (Lion Star), skillet, pan, trays, mills, donut maker tool, gas stoves (Hitachi), ovens (Hook), porcelain cups (Pyrex), aluminum dish, weighing bottles (Pyrex), measuring glass (Pyrex).

\section{Research Procedure}

\section{Research Methodology}

The experiment was design using a completely randomized design with the following composition:

A. Control (commercial yeast)

B. Wheat flour: potato paste: local yeast $(2: 1: 1)$

C. Wheat flour: potato paste: local yeast $(2: 1: 2)$

D. Wheat flour: potato paste: local yeast $(2: 1: 3)$

\section{Randomization and Research Layout}

Determination of treatment in the experimental unit was conducted randomly.

Data analysis method

Data were tabulated and analyzed using a one-way analysis of variance (ANOVA) according (Sugiyono, 2010).

\section{Research procedure}

\section{a. The process of making local yeast}

BanoEt (2018) reported that washing is the method that should be conducted before using the red fermented sap directly as yeast. The first step of the washing method is removing the red fermented sap from the fermentation container in the production house when the red fermented sap producer farmers harvest it. The remaining sediment in the fermentation container is taken using a plastic spoon, put in a jar, left for one hour until it completely settles, drained again until only semi-wet sediment is seen. The sediment is then washed in cold water that has been boiled before. The washing procedure is conducted as follows: the sediment is washed with water, with the ratio between the sediment and water is 1: 2. After washing, the sediment is rinsed five times until the sour aroma being disappeared. 


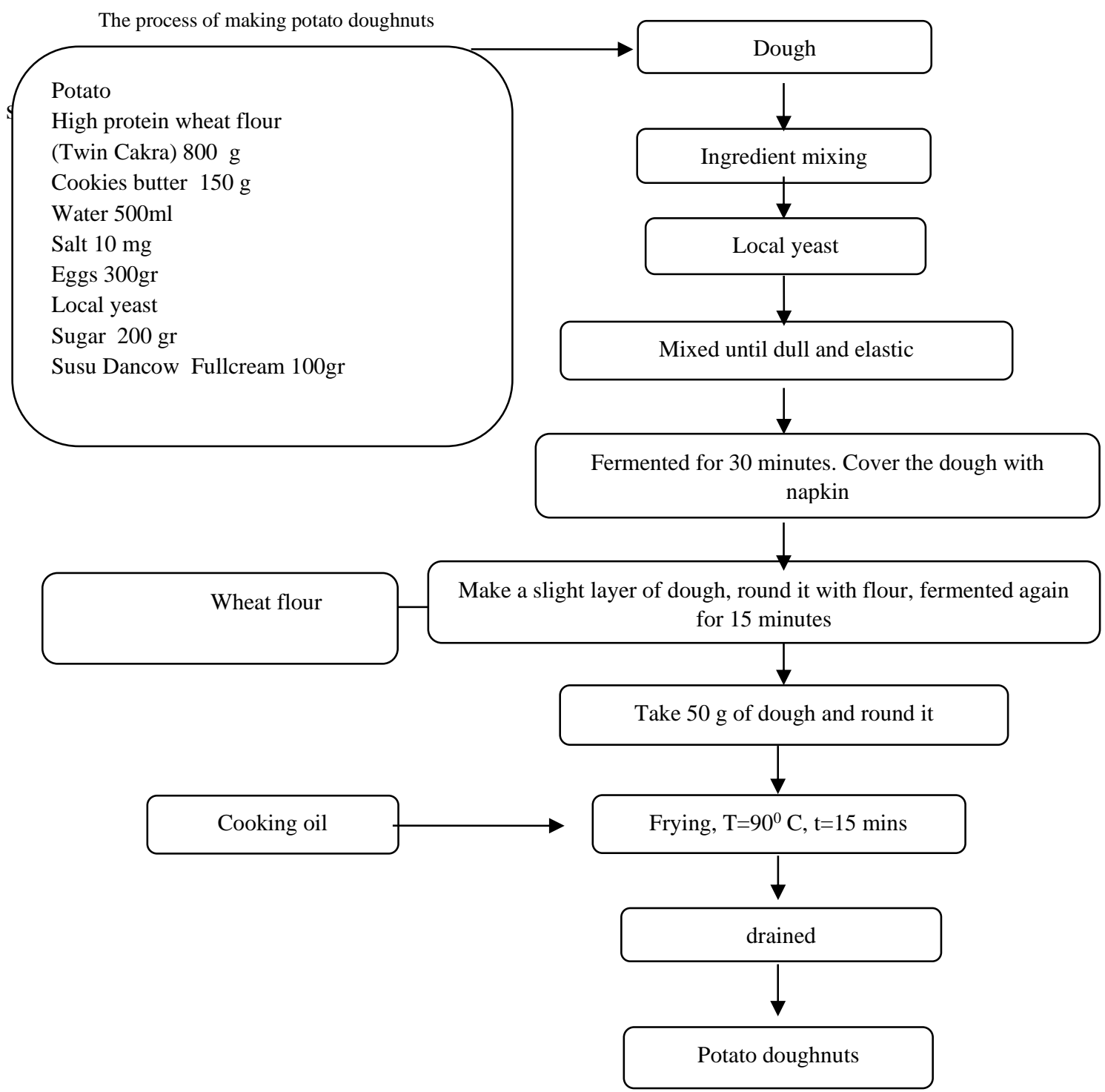

Figure 3.1 Flow chart of making potato doughnuts

Variables measured

\section{Moisture Content}

The moisture content of doughnuts was determined using the convection oven method. The principle of moisture content determination is to evaporate the water contained in the material with an oven (100$105^{\circ} \mathrm{C}$ ) for about 3-24 hours until all the chemically bound water evaporates or the weight of the material is constant. The moisture content of doughnuts was measured using the convection oven method.

\section{Organoleptic Test Method}

Sensory parameters evaluated in the present study were color, texture, taste, and aroma. The organoleptic test parameters were tenderness, color, flavor. Stages of implementing the organoleptic test:

\section{RESULTS AND DISCUSSION}

\section{Moisture Content}

The effect of treatments on the moisture content of doughnuts was summarized in Table 1. The moisture content of fried doughnuts formulated with 
wheat flour added with potato paste and local yeast (2:1:2 and 2:1:3, respectively) were significantly higher $(\mathrm{P}<0.05)$ than the control treatment; but were not different $(\mathrm{P}$ $>0,05)$ with treatment $\mathrm{B}$. No significant difference $(\mathrm{P}>0.05)$ in moisture content was observed between fried doughnuts formulated with wheat flour (control) and the fried doughnut which was formulated with wheat flour added with potato paste and local yeast $(2: 1: 1)$.

The high moisture content of fried doughnut in treatment $\mathrm{B}$ and $\mathrm{C}$ was probably due to the addition of local yeast (red fermented sap). Local yeast applied in the present study was a semi-liquid, so that it increased the water content of doughnuts and also change the doughnuts physical characteristics.

TABLE I

The effect of treatments on the moisture content of fried doughnut

\begin{tabular}{|l|c|}
\hline \multicolumn{1}{|c|}{ Treatment } & Moisture content (\%) \\
\hline Control (Wheat flour) & $20.179 \mathrm{~b}$ \\
\hline A. $\quad$ Wheat flour 200 + potato paste 100 + red fermented sap 100 & $20.602 \mathrm{ab}$ \\
\hline B. $\quad$ Wheat flour 200 + potato paste 100 + red fermented sap 200 & $22.770 \mathrm{a}$ \\
\hline C. $\quad$ Wheat flour 200 + potato paste 100 + red fermented sap 300 & $23.627 \mathrm{a}$ \\
\hline
\end{tabular}

${ }^{\mathrm{a}, \mathrm{b}}$ Means of the column with the superscripts significant difference $(\mathrm{P}<0$

Even though, no significant difference was found between treatments A, $\mathrm{B}$ and $\mathrm{C}$; however, the moisture content of fried doughnuts tended to increase as the level of local yeast increased. This could be the result of semi-liquid form of local yeast

\section{Protein Content}

The effect of treatments on the protein content of fried doughnut was presented in Table 2. Statistical analysis shows that doughnut formulation significantly affected $(\mathrm{P}<0.01)$ the protein content of fried doughnut. Doughnut formulated with heat flour added with potato paste and local yeast had lower $(\mathrm{P}<0.05)$ protein content compared to that of control treatment. The protein content of fried doughnuts in treatment $\mathrm{C}$ was lower $(\mathrm{P}<0.05)$ than those which were formulated using treatments A and B. No significant difference $(\mathrm{P}>0.05)$ in doughnut protein content was found between treatment $\mathrm{A}$ and B.

TABEL II

The effect of treatments on the protein content of fried doughnut.

\begin{tabular}{|c|c|}
\hline Treatment & Protein content $(\%)$ \\
\hline Control (Wheat flour) & $2.678 \mathrm{a}$ \\
\hline D. Wheat flour $200+$ potato paste $100+$ red fermented sap 100 & $2.095 \mathrm{~b}$ \\
\hline E. Wheat flour $200+$ potato paste $100+$ red fermented sap 200 & $2.068 \mathrm{~b}$ \\
\hline F. Wheat flour $200+$ potato paste $100+$ red fermented sap 300 & $1.965 \mathrm{c}$ \\
\hline
\end{tabular}

Journal Homepage:

http://ejournal.undwi.ac.id/index.php/jsds
Copyright (C) 2021 Dwijendra University. All right reserved. 
The decrease in protein content of doughnuts formulated with wheat flour added with potato paste and local yeast was probably due to the low protein content of potato paste and local yeast. (Kunimaru, 2021) reported that the protein content of potato was $1,9 \%$; while the protein content wheat flour was $0,50 \%$

Tenderness
Table 3 depicted the effect of treatment on the tenderness of fried doughnuts. Statistical analysis shows that the tenderness of fried doughnut was significantly affected $(\mathrm{P}<0.01)$ by the treatments. Fried doughnuts formulated with wheat flour added with potato paste and local yeast had lower tenderness $(\mathrm{P}<$ 0.05) value compared to that of control treatment.

TABEL III

The effect of different formulas on the average tenderness value of fried doughnuts.

\begin{tabular}{|c|c|}
\hline Treatment & Tenderness \\
\hline Control (Wheat flour) & $1061.250 \mathrm{~b}$ \\
\hline A. Wheat flour $200+$ potato paste $100+$ red fermented sap 100 & $1032.500 \mathrm{a}$ \\
\hline B. Wheat flour $200+$ potato paste $100+$ red fermented sap 200 & $1002.750 \mathrm{c}$ \\
\hline C. Wheat flour $200+$ potato paste $100+$ red fermented sap 300 & $851.875 \mathrm{c}$ \\
\hline
\end{tabular}

${ }^{a, b}$ Means of the column with the superscripts significant difference $(P<0.05)$

The present study proved that as the level of local yeast increased, the tenderness value decreased. This was probably due to the improvement in moisture content of the doughnuts. A well-developed doughnuts, as a bread diversification, indicated a good quality wheat flour used in terms of optimal gluten. A similar indication of good quality of ingredients was also implied for potato paste. When the semi-liquid yeast mixture obtained the optimal limit, so the tenderness of the doughnuts is an indication of well developed and tender doughnuts. A tender doughnut would be known by touching or tasting (pliable, and low repulsion to pressure or bite).

\section{Color}

Table 4 shows the effect of different formulas on the color of fried doughnut. As can be seen in Table 4, the color of the fried doughnuts was significantly $(P<0.01)$ affected by different doughnut formulations. The Duncan test revealed that fried doughnuts produced by formula $B$ and $\mathrm{C}$ had a similar preference $(\mathrm{P}>0.05)$, but they were different $(\mathrm{P}<0.05)$ from those which were formulated with formula $\mathrm{A}$ and control.

TABLE IV

The effect of different formulas on the average color value of fried doughnut

\begin{tabular}{|c|c|}
\hline Treatment & Color \\
\hline Control (Wheat flour) & $3.733 \mathrm{a}$ \\
\hline A. Wheat flour $200+$ potato paste $100+$ red fermented sap 100 & $3.800 \mathrm{a}$ \\
\hline B. Wheat flour $200+$ potato paste $100+$ red fermented sap 200 & $2.733 \mathrm{~b}$ \\
\hline C. Wheat flour $200+$ potato paste $100+$ red fermented sap 300 & $2.400 \mathrm{~b}$ \\
\hline
\end{tabular}

a,b Means of the column with the superscripts significant difference $(\mathrm{P}<0.05)$

Journal Homepage:

http://ejournal.undwi.ac.id/index.php/jsds
Copyright (C) 2021 Dwijendra University. All right reserved. 
The less color preference of fried doughnut added with local yeast was probably due to the change in doughnut color to reddish, as the color of local yeast is red. The color of the doughnuts or doughnut crumbs can be seen from the inside of the bread which makes up the doughnut cells. The color of the doughnut crumbs depend on the ingredients used and they can be virtually observed by comparing each color of doughnut crumbs.
Taste

The effect of different formulas on the average taste value of fried doughnuts is shown in Table 5. As can be seen in Table 5 , the taste values of fried doughnuts formulated with all types of formulas were found to be similar ( $\mathrm{P}>0.05)$. However, numerically, the taste values of fried doughnuts received treatment $\mathrm{B}$ and $\mathrm{C}$ were lower than control and treatment A.

TABEL V

The effect of different formula on the average taste value of fried doughnut

\begin{tabular}{|ll|c|}
\hline \multicolumn{1}{|c|}{ Treatment } & Taste \\
\hline \multicolumn{2}{|c|}{ Control (Wheat flour) } & $3,556 \mathrm{a}$ \\
\hline A. $\quad$ Wheat flour 200 + potato paste 100 + red fermented sap 100 & $3,644 \mathrm{a}$ \\
\hline B. $\quad$ Wheat flour 200 + potato paste 100 + red fermented sap 200 & $3,067 \mathrm{a}$ \\
\hline C. $\quad$ Wheat flour 200 + potato paste 100 + red fermented sap 300 & $2,600 \mathrm{a}$ \\
\hline
\end{tabular}

The insignificant differences among all treatment formulas were in agreement with (BanoEt et al., 2018) who found that no difference in genetics between local yeast and commercial yeast, Saccharomyces cerevisiae.

\section{CONCLUSIONS}

Based on the results and discussion, it can be concluded that

1. The different doughnut formulas resulted in a significant difference $(\mathrm{P}>$ $0,01)$ in physical (color, taste, texture) and chemical (protein and moisture contents) characteristics of fried doughnuts.

\section{REFERENCES}

Apriyantono, A. (2009). Reaching Rice Self-Sufficiency. Agriculture Department Indonesian.

Banoet R. I. M, 2016. The benefit of several types of microbes isolated from laru wood (Pelthoporum pterocarpum) and
2. The best treatment was achieved in treatment A ( 2 wheat flour: 1 potato paste: 1 local yeast) with $20.6 \%$ moisture content, $2.09 \%$ protein content and 3.64 color value (very like), 3.80 taste value (very like), and 1032.5 texture/tenderness value.

\section{ACKNOWLEDGEMENT}

The authors would like to thank the Christian University of Artha Wacana that has provided funding for this research University in 2020.

fermented sap as starter in making laru and palm alcohol (sopi) in West Timor. Journal of Agricultural Science and Biotechnology.5 (1):6..... [Indonesian].

BanoEt, R. I. M. (2017). The Use of Red 
Fermented Sap as a Local Yeast on the Bread Making Without Cassava Flour. Proceeding of National Seminar of Faculty of Mathematics and Natural Science, University of Nusa Cendana: Renewable Energy to Support the Development in Dry Land Area.

BanoEt, R. I. M., Medah, A. M., Manafe, M., Alit, M., \& Sudana. (2018). The use of conveniently Red Laru Mur as local yeast sources in bread making without cassava flour substitution. Ecology, Environment and Conservation, $\quad 25, \quad 84-88$. www.envirobiotechjournals.com.

Budiyanto, M. A. K. (2004). Applied microbiology (3rd ed.). UMM Press.

Ko Sangjin. (2012). The Secret of Making Healthy and Delicious Bread with Natural Yeast. Indonesia Tera.

Kunimaru, et al. (2021). Ease of Swallowing Potato Paste in People with Dysphagia: Effect of Potato Variety. International Journal of Food Properties, 24(1), 615-626.

Sugiyono. (2010). Statistika untuk Penelitian. Alfabeta. 